\title{
The Prevalence of Hepatitis C Virus Ribonucleic Acid, the Risk Factors, and Relation with Aminotransferase Levels in a General Population of Jakarta, Indonesia
}

Nurul Akbar

\begin{abstract}
Abstrak
Untuk mengetahui prevalensi asam ribonukleat virus hepatitis C (HCV RNA) dan hubungannya dengan enzim transferase pada populasi umum. Penelitian ini dilakukan dari Januari sampai Juni 1994, pada 7,017 rumah tangga yang meliputi 34,666 orang. Sejumlah 978 responden yang tidak ada anggota keluarga berumur diatas 15 tahun dari 340 rumah tangga yang terpilih secara random diwawancarai tentang demografi, faktor risiko serta diperiksa anti bodi virus hepatitis $C$ (anti-HCV), HCV RNA, aspartate aminotransferase (AST), dan alanine aminotransferase (ALT). HCV RNA ditemukan pada 44.8\% (13/29) dari responden dengan anti-HCV positif. Terdapat kecenderungan amat kuat antara bertambahnya umur dengan HCV RNA positif $(p<0.001)$. Keadaan sosioekonomi berhubungan secara signifikan dengan HCV RNA positif. $(p=0.0282)$ Beberapa faktor risiko (riwayat sakit kuning, riwayat operasi, sakit kuning pada keluarga, minum alkohol, merokok) tidak berhubungan dengan HCV RNA. ALT dan AST lebih meningkat secara signifikan pada HCV RNA positif (adjusted OR=6.25, 95\% CI: $1.07-15.41$ dan adjusted OR= 3.78, 95\% CI:1.20-11.90, berturut-turut). Prevalensi HCV RNA pada keturunan Cina tidak lebih tinggi dibanding dengan Melayu asli $(p=0.2729)$. Banyak anggota dalam satu rumah tangga dan riwayat operasi berasosiasi sedang dengan HCV RNA positif. $(p=0.0678$ and $p=0.0754$ berturut-turut). Riwayat pendidikan berasosiasi lemah dengan HCV RNA positif. Riwayat transfusi merupakan faktor risiko yang signifikan untuk HCV RNA (adjusted $O R=4.06,95 \%$ CI: 1.07-15.41). HCV RNA ditemukan pada sekitar setengah dari responden dengan anti-HCV positif. ALT dan AST lebih meningkat secara signifikan pada subyek dengan HCV RNA positif.
\end{abstract}

\begin{abstract}
This study identifies hepatitis $C$ virus infection (HCV) and measures ribonucleic acid of hepatitis $C$ virus (HCV RNA) and it's relation to aminotransferase levels in the general population of Jakarta. A population-based sample of 978 people, aged 15 and above was surveyed. Specially trained nurse-midwives conducted structured interviews with the subjects regarding demographic characteristics and some risk factors for HCV infection. Serum was analyzed for antibody to HCV (anti-HCV), HCV RNA, aspartate aminotransferase (AST), and alanine aminotransferase (ALT). HCV RNA was found in 44.8\% (13/29) among positive anti-HCV cases. There was a strong positive trend between age and risk of positive HCV RNA $(p<0.001)$. Socioeconomic status was associated with HCV RNA $(p=0.0282)$. The history of transfusion was strongly associated with HCV RNA (adjusted OR= 4.06, 95\% CI: 1.07- 15.41). ALT and AST were significantly elevated in HCV RNA+ cases compared to HCV RNA-cases (adjusted OR=6.25, 95\% CI: $1.07-15.41$ and adjusted $O R=3.78,95 \%$ CI: $1.20-11.90$, respectively). Family size and history of surgery were moderately associated with HCV RNA. ( $p=0.0678$ and $p=0.0754$, respectively) Education levels were weakly associated with HCVRNA. $(p=0.3462)$. Some risk factors such as ethnic group, current drinking habit, smoking habit, and education level were not associated with HCV RNA. The prevalence of HCV RNA among Indonesian natives are similar with those of Chinese descendants $(p=0.2729)$. HCV RNA as a marker of HCV actual infection is found in about half of the positive anti-HCV cases. Positive HCV RNA cases showed higher aspartate aminotransferase and alanine aminotransferase levels than negative HCV RNA cases.
\end{abstract}

Keywords: Risk factors, HCV RNA, ALT, AST, general population

\section{INTRODUCTION}

The genome of a parenterally transmitted non-A, non$B$ hepatitis virus was identified recently using the

Department of Internal Medicine, University of Indonesia School of Medicine/Dr. Cipto Mangunkusumo Hospital, Jakarta, Indonesia recombinant DNA technique. Hepatitis C virus (HCV) contains a positive-stranded ribo nucleic acid (RNA) genome of roughly 10.000 nucleotides. The development of a sensitive test for anti-body to hepatitis C virus infection (anti-HCV) has shown that this virus is an important cause of acute and especially chronic hepatitis worldwide. Anti-HCV is used to recognize recent and past infection of $\mathrm{HCV}$. 
The majority of patients, at least $80 \%$, develop a chronic infection after contact with the hepatitis $\mathrm{C}$ virus. Chronic hepatitis $C$ virus infection was defined as a persistent viremia (positive of HCV RNA and/or transaminases) for more than 6 months. ${ }^{1}$ Questions have been raised regarding the status of samples that are reactive in anti-HCV test with respect to falsepositivity and viral load of hepatitis $\mathrm{C}$ virus ( $\mathrm{HCV}$ RNA). ${ }^{2}$

Alanine aminotransferase (ALT) and aspartate aminotransferase (AST) are the serum enzyme indicator of hepatocellular damage in subjects with acute and chronic hepatitis. Fluctuation of ALT activity inpatients with chronic hepatitis $\mathrm{C}$ virus (HCV) infection is well-recognized. ${ }^{1}$ The serum ALT activity in relation to HCV infections among the general population has not been well elucidated. Most previous studies of the epidemiology of anti-HCV have focused on special groups such as blood donors, hemophilia patients, and transfusion recipients who were at risk as a result of percutaneous exposures to blood products, ${ }^{3-8}$ however most HCV infections are currently outside the transfusion setting. ${ }^{3,4}$ Epidemiological studies among blood donor population and hospital-based population might not really represent the general population. ${ }^{9}$

This study aimed to assess the prevalence of $\mathrm{HCV}$ infection, using HCV RNA as a marker of HCV actual infection and serum ALT/AST activity among the general population.

\section{MATERIALS AND METHODS}

This study was conducted from January to June 1994 in an urban subdistrict of Central Jakarta, Indonesia and consisted of 34,666 people in 7,017 households. Household members aged 15 and above were asked to participate. A total of 1,150 subjects from 340 randomly selected households were eligible to participate in the study. Blood samples for the examination of antiHCV, HCV RNA, AST, and ALT were taken. Specially trained nurse-midwives visited the eligible subjects to invite them to visit a local, participating hospital for this study. The nurse-midwives then conducted structured interviews on the subjects at the participating hospital regarding demographic characteristics and risk factors for $\mathrm{HCV}$ infection.

Self-reported factors under study included gender, age (15-29, 30-49, 50 and above), current alcohol use (yes/no), current smoking habit (yes/no), history of transfusion (ever/never), history of jaundice (ever/never), family history of jaundice (ever/never) and history of surgery (yes/no).

AST and ALT laboratory tests were carried out using laboratory kit tests from Boehringer Mannheim $\mathrm{GmbH}$. Normal AST level is less than $38 \mathrm{IU} / \mathrm{dl}$ for male, and less than $32 \mathrm{IU} / \mathrm{dl}$ for female; normal ALT level is less than $42 \mathrm{IU} / \mathrm{dl}$ for male, and less than 32 IU/dl for female.

Anti-HCV findings were done using a dipstick test developed at Laboratoria Hepatika Mataram, Lombok, Indonesia. This test utilizes HCV-core-derived synthetic peptides CP9 (aa 39-74) and CP14 (aa 5-40) as solid antigens, which are recognized by anti-core antibodies. It has been shown to have equal sensitivity to commonly used second-generation enzyme-linked immunosorbent assay (anti-HCV Elisa II Ortho Diagnostics Systems Tokyo). ${ }^{13}$ All sera were collected and kept at minus 20 degrees Celsius prior to the assessment. The presence of HCV RNA was evaluated by the -Amplicor HCV semi-quantitative test, a combined reverse transcription-polymerase chain reaction (RTPCR) assay (Roche Diagnostic Systems) in the Liver Unit, Department of Internal Medicine, University of Indonesia, Ciptomangunkusumo Hospital, Jakarta, Indonesia. The Amplicor HCV Test uses the primers KY78 and KY80 to define a 244-nucleotide sequence within highly 5 '-untranslated region.

A number of 1020 respondents out of 1150 invited subjects $(89 \%)$ participated in this study. We excluded 32 out of 1020 subjects due to incomplete and/or conflicting data. Thirty-nine out of 988 (3.9\%) subjects were positive for anti-HCV. Twenty-nine out of 38 anti-HCV positive subjects were tested for $\mathrm{HCV}$ RNA. We could not test HCV RNA among 10 positive anti-HCV cases because of the shortage of sera. Therefore only 978 subjects were analyzed in this paper.

The excluded 32 subjects consisted of 14 male and 18 female. By age group there were 12 persons aged 15-29 years old, 9 persons aged 30-49 years old, and 11 persons aged 50 years and over. In term of gender and age group the excluded subjects were not significantly different with the 978 subjects which were included in this analysis.

Frequencies between groups were compared by Fisher'exact ${ }^{21}$ test or chi-square test. Logistic regression analysis ${ }^{22}$ was used to control the confounding effects of other characteristics and exposures on the relation to HCV RNA. A variable was considered to be 
a confounder if its inclusion in a model changed the odds ratio by more than $10 \%$. Characteristic that fulfilled this definition as confounder are included in the models presented. Odds ratios were estimated by the method of maximum likelihood, and their $95 \%$ confidence intervals $(\mathrm{CI})$ were based on the standard error of coefficient estimates.

The Ethics Committee of the Department of Internal Medicine School of Medicine University of Indonesia approved this study. Informed consent was obtained from participants in this study.

\section{RESULTS}

HCV RNA were detected in 13 out of 29 (44.8\%) anti $\mathrm{HCV}$ positive cases. HCV RNA positive subjects were similarly distributed with respect to gender. Socioeconomic status was significantly associated with HCV RNA ( $p=0.0282)$. Family size was moderately associated with HCV RNA. Education levels were weakly associated with HCV RNA. Some risk factors as ethnic group, current drinking habit, smoking habit, and education level were not associated with HCV RNA. History of surgery as a medical risk factor was moderately associated with HCV RNA. Other medical risk factors (such as ever having jaundice, family history of jaundice) were not associated with anti-HCV (Table 1).

The results of a suitable model for HCV RNA consisted of variables of ALT, AST, and history of transfusion were shown on table 2.

Table 1. Some characteristic of subjects

\begin{tabular}{|c|c|c|c|c|c|}
\hline & \multicolumn{4}{|c|}{ HCV RNA status } & \multirow[b]{3}{*}{$\mathrm{P}$} \\
\hline & \multicolumn{2}{|c|}{ Positive } & \multicolumn{2}{|c|}{ Negative } & \\
\hline & Number & $\%$ & Number & $\%$ & \\
\hline \multicolumn{6}{|l|}{ Gender } \\
\hline Male & 7 & $53.8 \%$ & 447 & $46.3 \%$ & $0.7945^{*}$ \\
\hline Fernale & 6 & $46.2 \%$ & 518 & $53.7 \%$ & \\
\hline \multicolumn{6}{|l|}{ Ethnic group } \\
\hline Indonesian native & 11 & $84.6 \%$ & 890 & $92.2 \%$ & $0.2729^{*}$ \\
\hline Chinese & 2 & $15.4 \%$ & 75 & $7.8 \%$ & \\
\hline \multicolumn{6}{|l|}{$\begin{array}{l}\text { Socioeconomic status } \\
\text { High }\end{array}$} \\
\hline High & 6 & $46.2 \%$ & 231 & $23.9 \%$ & $0.0282 * *$ \\
\hline Middle & 6 & $46.2 \%$ & 315 & $32.6 \%$ & \\
\hline Low & 1 & $7.7 \%$ & 419 & $43.4 \%$ & \\
\hline \multicolumn{6}{|l|}{$\begin{array}{l}\text { Education Level } \\
\text { High }\end{array}$} \\
\hline High & 4 & $30.8 \%$ & 200 & $20.7 \%$ & $0.3462 * *$ \\
\hline Middle & 8 & $61.5 \%$ & 535 & $55.4 \%$ & \\
\hline Low & 1 & $7.7 \%$ & 230 & $23.8 \%$ & \\
\hline \multicolumn{6}{|l|}{ Family size } \\
\hline 1-2 persons & 6 & $46.2 \%$ & 282 & $29.2 \%$ & $0.678^{* *}$ \\
\hline 3-4 persons & 1 & $7.7 \%$ & 378 & $39.2 \%$ & \\
\hline 5 persons and over & 6 & $46.2 \%$ & 305 & $31.6 \%$ & \\
\hline \multicolumn{6}{|l|}{$\begin{array}{l}\text { Drinking habit } \\
\text { No }\end{array}$} \\
\hline No & 13 & $100.0 \%$ & 913 & $94.6 \%$ & $1.00^{*}$ \\
\hline Yes & 0 & 0 & 52 & $5.4 \%$ & \\
\hline \multicolumn{6}{|l|}{$\begin{array}{l}\text { Smoking habit } \\
\text { No }\end{array}$} \\
\hline No & 8 & $61.5 \%$ & 725 & $75.1 \%$ & $0.3577^{*}$ \\
\hline Yes & 5 & $38.5 \%$ & 240 & $24.9 \%$ & \\
\hline \multicolumn{6}{|l|}{$\begin{array}{l}\text { History of jaundice } \\
\text { Never }\end{array}$} \\
\hline Never & 11 & $84.6 \%$ & 892 & $92.4 \%$ & $0.4508^{* *}$ \\
\hline Ever & 2 & $15.4 \%$ & 65 & $6.7 \%$ & \\
\hline Unknown & 0 & 0 & 8 & $.8 \%$ & \\
\hline \multicolumn{6}{|c|}{$\begin{array}{l}\text { Family history on hepatitis } \\
\text { None }\end{array}$} \\
\hline None & 9 & $69.2 \%$ & 791 & $82.4 \%$ & $0.4486^{* *}$ \\
\hline Exist & 3 & $23.1 \%$ & 116 & $12.0 \%$ & \\
\hline Unknown & 1 & $7.7 \%$ & 58 & $.6 \%$ & \\
\hline \multicolumn{6}{|l|}{$\begin{array}{l}\text { History of Surgery } \\
\text { Never }\end{array}$} \\
\hline Never & 8 & $61.5 \%$ & 788 & $81.7 \%$ & $0.0754^{*}$ \\
\hline Ever & 5 & $38.5 \%$ & 117 & $18.3 \%$ & \\
\hline
\end{tabular}

* Fischer exact test, two tailed

* Chi-square test 
Table. 2 Medical risk factors related to HCV RNA

\begin{tabular}{lrrl}
\hline & \multicolumn{2}{c}{ HCV RNA status } & OR* (95\% CI) \\
\cline { 2 - 3 } & $\begin{array}{c}\text { Positive } \\
(\mathrm{n}=13)\end{array}$ & $\begin{array}{c}\text { Negative } \\
(\mathrm{n}=965)\end{array}$ & \\
\hline $\begin{array}{l}\text { Tranfusion history } \\
\text { Never }\end{array}$ & 10 & 900 & 1.00 (reference) \\
$\quad$ Ever & 3 & 65 & $4.06(1.07-15.41)$ \\
$\quad$ & & & \\
ALT & 11 & 932 & 1.00 (reference) \\
$\quad$ Normal & 2 & 33 & 6.25 (1.26-30.94) \\
$\quad$ Increased & & & \\
$\quad$ AST & 8 & 813 & 1.00 (reference) \\
$\quad$ Normal \\
$\quad$ Increased & 5 & 152 & 3.78 (1.20-11.90) \\
\hline
\end{tabular}

* Odds ratio adjusted for socioeconomic status and education levels.

Elevated ALT and AST were strongly associated with HCV RNA positive cases (adjusted $\mathrm{OR}=6.25,95 \% \mathrm{CI}$ : 1.07-15.41 and adjusted $\mathrm{OR}=3.78,95 \% \mathrm{CI}: 1.20-$ 11.90 , respectively).

The history of transfusion was strongly associated with HCV RNA (adjusted OR=4.06, 95\% CI: 1.07- 15.41) The trend on the age to HCV RNA was demonstrated in Table 3. There was a strong positive trend between age and the risk of HCV RNA positive. $(p<0.001)$

Table 3. Trend on age group to HCV-RNA

\begin{tabular}{lccc}
\hline & \multicolumn{2}{c}{ HCV-RNA status } & \\
\cline { 2 - 3 } & $\begin{array}{c}\text { Positive } \\
(\mathrm{n}=13)\end{array}$ & $\begin{array}{c}\text { Negative } \\
(\mathrm{n}=965)\end{array}$ & \\
\hline Age group & & & \\
15-29 years & 2 & 744 & 1.00 (reference) \\
30-49 years & 8 & 138 & $20.04(4.19-95.96)$ \\
$50+$ years & 3 & 83 & $13.33(2.19-81.20)$ \\
\hline
\end{tabular}

* Odds ratio adjusted for transfusion history.

In general, HCV RNA positive was moderately associated with the number of persons in a household.

We assumed that there were no acute hepatitis cases found in our study because the maximum range of AST and ALT among our subjects were less than 2.5 times the normal limits. The range of AST in our study was 11 to $92 \mathrm{U} /$, while ALT ranged from 9 to $87 \mathrm{U} / \mathrm{l}$.

\section{DISCUSSION}

There are some limitations that must be considered in the interpretation of our findings. We could not test HCV RNA among 10 anti-HCV positive cases because of the shortage of sera, and also genotypes of HCV in all cases. In spite of these limitations, the value of our observations derives largely from the use of a general population sample to estimate the prevalence of actual $\mathrm{HCV}$ infection in Indonesia.

Anti-HCV can be detected in recent (actual) and past infection of hepatitis $\mathrm{C}$ virus. A previous study in Indonesia found the prevalence of anti-HCV to be 2.5 percent among blood donors, using a first generation test (anti-C100 - ELISA/Ortho). ${ }^{10}$ This figure was lower compared to our findings. Our findings of a higher prevalence of anti-HCV (3.9\%) may reflect our use of a newer, more sensitive test rather than any true difference in risk of $\mathrm{HCV}$ or differences of respondents that we used. In line with the present study, another population-based study conducted in Jakarta in other urban areas found the prevalence of anti-HCV to be 4.4 $\%$ using a commercial available third generation assay Innotest, from Innogenetics N.V. Ghent, Belgium . ${ }^{15}$ Another study on extensive blood donors throughout Indonesia found the prevalence of anti-HCV among blood donors was 2.1 percent nationwide and 2.5 percent in Jakarta, using a second generation immunosorbent assay. After adjustment for age (most of blood donors age were younger compared to the age of population in our study), their estimates of anti-HCV prevalence were virtually identical to ours, but in other islands of Indonesia such as Sumatra, Sulawesi, Eastern Indonesia, they reported that the prevalence of anti-HCV among blood donors were lower compared to our findings, $1.7 \%, 1.8 \%$ and 1.0 respectively. ${ }^{11}$

Our study revealed that actual infection of $\mathrm{HCV}$ (HCV RNA positive) was found in $44.8 \%$ of anti-HCV positive cases, which were tested. We found there was a strong trend that the prevalence of HCV RNA was increased according to age. Many studies also indicate that the seroprevalence of anti-HCV in blood donors and healthy individuals rises with age. ${ }^{12,14,20}$

Our data showed that socioeconomic status was associated with HCV RNA ( $\mathrm{p}=0.0282$ ). This finding was not in line with other studies on association of anti$\mathrm{HCV}$ and socioeconomic status. ${ }^{15,20}$ The familial size was moderately associated with HCV RNA. Furthermore we found that for each household only one member were HCV RNA positive. We noted that the Chinese population was also found not to be suscep- 
tible in developing HCV RNA (Table 1). These findings are in agreement with a previous report in Indonesia. 15

The cases with positive HCV RNA are contagious and can potentially transmit hepatitis $\mathrm{C}$ virus. In spite of the fact that we do not have any data about actual HCV infection among Indonesian blood donors, the relatively high prevalence of true $\mathrm{HCV}$ infection among the general population may also occur among anti-HCV positive blood donors. Therefore screening of blood donors for HCV should be performed to prevent transmission to recipients. In developing countries including Indonesia, nation wide blood donor screening is not yet performed due to the cost of commercially available ELISA kit to detect anti-HCV. The Entebe AntiHCV Dipstick, an Indonesian product, manufactured by Hepatika Mataram Indonesia which is a simple, rapid and economical although not superior than ELISA in sensitivity, can be useful in blood centers. ${ }^{13}$ A single anti-HCV assay can be completed within 60 minutes using this dipstick.

The value of screening blood donors for hepatitis $\mathrm{C}$ virus using ALT has been debated in the literature. Anti-HCV ELISA reactivity and raised ALT levels have been studied in blood donors. In the 7366 donors screened for anti-HCV, $40(0.54 \%)$ were reactive by ELISA and 10 out of 40 (25\%) had raised ALT. ${ }^{16}$ Our data showed that ALT and AST were elevated significantly in HCV RNA positive cases compared to normal subjects. Although ALT test is an indicator of liver cell necrosis, its raise may also be influenced by other viral agents as well as by age, gender, obesity, drugs, and especially alcohol. In our cases, there was no influence of alcohol but we did not have data about the nutritional condition of the subjects. A study from South Africa reported, no blood donors with positive anti-HCV had elevated ALT but among anti-HCV non-reactive blood donors raised ALT were found in $3.4 \%$ of black donors, $5.6 \%$ of whites, and $11.2 \%$ of Asian. This report did not discuss the discrepancy of ALT elevated among these races. ${ }^{17}$ Our study revealed that the increment of ALT and AST levels in HCV RNA positive cases were found in $15.4 \%$ and $38.5 \%$ of cases respectively, but it may not be useful to screen HCV infection among blood donors with the increment of aminotransferase alone.

The correlation between the raised transaminases and actual infection of HCV in our study is statistically significant compared to normal subjects. This finding showed a correlation between liver cell necrosis as expressed by the elevated ALT and actual HCV infection. Formerly there were some scepticism about the raised transaminases as to whether HCV infection represented anything more than unspecific transaminitis in a largely asymptomatic cases. Some studies disclosed that up to $80 \%$ of the patients with the diagnosis of mildly active hepatitis progressed to severely active chronic hepatitis or liver cirrhosis within 5 to 11 years of observation. ${ }^{18,19}$ On the other hand there were some patients who have consistently normal transaminases values despite the presence of HCV RNA in the serum. The histological findings in this group were conflicting. About $50 \%$ of the cases had significant abnormal liver pathology but most lesions were not severe. ${ }^{19}$ Prognostication is difficult in the case of persistent HCV RNA. ALT activity fluctuates and can be normal for weeks or months. Serial liver biopsies are important, especially inpatients with persistently abnormal ALT activity. Despite of the overall severity of chronic hepatitis $\mathrm{C}$ and its controversionality; there is no doubt that $\mathrm{HCV}$ can progress to liver cirrhosis and liver cell carcinoma. Therefore HCV RNA positive cases should be monitored carefully to assess the possibility of chronic hepatitis and the need for anti viral treatment.

\section{CONCLUSION}

Positive HCV RNA as an actual HCV infection is found among about half of anti-HCV positive cases. $\mathrm{HCV}$ infection raised aspartate aminotransferase and alanine aminotransferase levels (as an indicator of liver cell damage) more than in (the negative) HCV-RNA.

\section{Acknowledgments}

The author is indebted to Dr. Sarwono Waspadji for his help in coordinating the field study for samples collection, to Dr. Bastaman Basuki for his great effort in reviewing the data, to Prof. H. M. Sjaifoellah Noer for the valuable comments and to Prof. Muljanto for his assistance with the anti-HCV assay. Test kits of AST and ALT were generously provided by Boehringer Mannheim GmbH.

\section{REFERENCES}

1. Choo Q-L, Kuo G, Weiner AJ, Overby LR, Bradley DW, and Hougton M. Isolation of a cDNA Clone derived from a blood borne non-A, non-B viral hepatitis genome. Science 1989;244:359-62

2. Mc Farlane IG, Smith HM, Johnson PJ, Bray GP, Vergani $\mathrm{D}$, and William R. Hepatitis $\mathrm{C}$ virus anti-bodies in chronic active hepatitis: Pathogenic factor or false-positive result? Lancet 1990; 335:754-7 
3. Alter ME. Epidemiology of hepatitis $\mathrm{C}$ in the west. Semin Liver Dis 1995; 15: 5-13

4. Mansell CJ, Locarnini SA. Epidemiology of hepatitis $C$ in the east. Semin Liver Dis 1995; 15: 15-32.

5. Farrell GC, Weltman M, Dingley J, Lin R. Epidemiology of hepatitis C infection in Australia. Gastroenterol Jpn 1993; 28 (Suppl 5): 32-6.

6. Conry-Cantilena C, Van Raden M, Gibble J, Melpolder J, Shakil OA, Viladomiu L, et al. Routes of infection, viremia, and liver disease in blood donors found to have hepatitis C virus infection. N Engl J Med 1996; 334: 1691-6

7. Thuring EG, Joller-Jemmelka HI, Sareth M, Sokhan U, Retch $C$ and Grob P. Prevalence of markers of hepatitis viruses $\mathrm{A}, \mathrm{B}, \mathrm{C}$ and of HIV in healthy individuals and patients of a Cambodian province. Southeast Asian J Trop Med Public Health 1993; 24: 239-49.

8. Esteban R, Esteban JI, Lopez-Talavera JC, Genesca J, Buti M, Vargas V, et al. Epidemiology of hepatitis $C$ virus infection. In: Hollinger FB, Lemon SM, Margolis HS, eds. Viral hepatitis and liver disease. Baltimore; Williams and Wilkins, 1991: 413-5

9. Seeff LB. Foreword. Semin Liver Dis 1995; 15: 1-3.

10. Budihusodo U, Sulaiman HA, Akbar HN, Lesmana LA, Waspodo AS, Noer HMS, et al. Seroepidemiology of HBV and HCV infection in Jakarta, Indonesia. Gastroenterol Jpn 1991; 26 (Suppl 3): 196-201.

11. Sulaiman HA, Julitasari, Sie A, Rustam M, Melani W,Corwin A, et al. Prevalence of hepatitis B and C in healthy Indonesian blood donors. Trans R Soc Trop Med Hyg 1995; 89: $167-70$

12. Lee SD, Chan CY, Wang YJ, Wu JC, Lai KH,Tsai YT, et al. Seroepidemiology of hepatitis $\mathrm{C}$ virus infection in Taiwan. Hepatology 1991; 13: 830-3.

13. Mulyanto, Suwignyo S, Tsauri S, Itoh K, Mizui M,Tsuda F, et al. An easy dipstick assay for anti-core antibodies to screen blood donors for hepatitis $\mathrm{C}$ virus viremia. Vox Sang 1996; 70: 229-31
14. Yano $M$, Yatsuhashi $H$, Inoue $O$, Inokuchi $K$, Koga $M$. Epidemiology and long term prognosis of hepatitis $\mathrm{C}$ virus infection in Japan. Gut 1993; 34 (Suppl 2): S13-6.

15. Suwandhi W. Epidemiology hepatitis $B$ and hepatitis $C$ virus infection in an urban area in Jakarta, Indonesia: A hospital and population based study. Doctoral Dissertation. Leuven, Catholic University Leuven, Belgium. 1996.

16. Hyland CA, Morgan C, Parker SL, Keams S, Bailey L, Westguard RJ, et al. Correlation between alanine aminotransferase levels and hepatitis $\mathrm{C}$ virus antibody detection in blood donors. In: Hollinger FB, Lemon SM, Margolis HS, eds. Viral hepatitis and liver disease. Baltimore; Williams and Wilkins, 1991: 439-41

17. Ellis LA, Brown D, Conradie JD, Paterson A, Sher R, Millo $\mathrm{J}$, et al. Regional prevalence of Hepatitis $\mathrm{C}$ antibodies in South Africa: An analysis of fresh and stored serum. In: Hollinger FB, Lemon SM, Margolis HS, eds. Viral hepatitis and liver disease. Baltimore; Williams and Wilkins, 1991 : 445-7

18. Healey CJ, Chapman RW, Fleming KA. Liver histology in hepatitis $\mathrm{C}$ infection: a comparison between patients with persistently normal or abnormal transaminases. Gut 1995 Aug;37(2):274-8

19. Takahashi M, Yamada G, Miyamoto R, Doi T, Endo H, and Tsuji T. Natural course of chronic hepatitis C. Am J Gastroenterol 1993 Feb;88(2):240-3

20. Akbar N, Basuki B, Mulyanto, Garabrant DH, Sulaiman A, Noer HMS. Ethnicity, socio economic status, transfusion and risk of hepatitis $B$ and hepatitis C infection. J Gastroenterol Hepatol (in press).

21. Armitage P. Statistical methods in medical research. New York: John Wiley, 1971: 135-8

22. Breslow NE, Day NE. Statistical methods in cancer research. Vol. I. The analysis of case-control studies. IARC Scientific Publications No. 32. Lyon, France, International Agency for Research on Cancer; 1980. 